e-ISSN: 2564 - 6664 \\ DOI: $\underline{10.33716 / \text { bmedj.1007824 }}$}

${ }^{1}$ M.D., Prof. Dr. Cemil Taşcioğlu City Hospital, Department of Pediatric Infection, Istanbul, Turkey

${ }^{2}$ Res. Asst., Düzce University, School of Medicine, Department of Pediatrics,Düzce, Turkey

${ }^{3}$ M.D., Sakarya University School of Medicine, Department of Pediatric Surgery, Sakarya, Turkey.

${ }^{4}$ M.D., Çaycuma State Hospital, Department of Pediatrics, Zonguldak, Turkey.

${ }^{5}$ M.D., Düzce University, School of Medicine, Department of Pediatric Emergency, Düzce, Turkey.

${ }^{6}$ Prof. Düzce University, School of Medicine, Department of Pediatrics, Düzce, Turkey.

Sorumlu Yazar: Önder Kilıçaslan, M.D., Prof. Dr. Cemil Tascioglu City Hospital, Department of Pediatric Infection, Istanbul, Turkey. E-mail:dronderklcsIn@gmail.com Telefon: +90 5065962784 .

Başvuru Tarihi: 10.10.2021 Kabul Tarihi: 25.11 .2021 Yayınlanma Tarihi: 30.11.2021

Atıf İçin: Önder Kılıçaslan, Betül Türen, Aybars Özkan, Gülden Ak, Ramazan Cahit Temizkan, Kenan Kocabay, Foreign body aspiration in children: A survey based study, 2021;5(3):144-150.

\section{Foreign body aspiration in children: A survey based study}

\section{Çocuklarda yabancı cisim aspirasyonu: Anket tabanlı bir çalışma}

\author{
Önder Kılıçaslan¹, (D) Betül Türen², (D) Aybars Özkan², (D) Gülden Ak4,
}

iD Ramazan Cahit Temizkan ${ }^{5}$, (iD Kenan Kocabay ${ }^{6}$

\section{ABSTRACT}

Aim: Foreign body aspiration (FBA) is a life-threatening emergency that causes airway obstruction. This study aims to investigate the amount of awareness there is about the life-threatening emergency FBA among Turkish mothers who are full-time carers of their children, and to provide these mothers with information regardless of their answers. Material and Method: 1034 mothers with children between 6 months and 5 years old were included in the study. Participants were asked to provide their sociodemographic information and to answer questions about FBA. Result: She majority of the mothers were aged between $21-30$ years old (48.94\%), primary school graduates (34.62\%), and housewives (66.05\%). The families had two to three children in general. Most of the mothers (65.73\%) had not seen a child experiencing FBA. If we compared the mothers according to level of education, "1-3 years" was mostly selected by the university graduates $(66.19 \%)$ as the age group in which FBA was most prevalent. As the level of education increased, the awareness regarding FBA's potential lethality, the importance of preventive measures, the importance of first response, and sources for correct information on how to intervene were seen to increased. While most of the participants (72.74\%) stated that they would take the child to the emergency room in the event of FBA. Conclusion:The most important step in reducing the morbidity and mortality of FBA is prevention. The easiest way to prevention is education of parents and the raising of public awareness.

Keywords: Foreign body; child; mother; knowledge; attitudes

\section{Öz}

Amaç: Yabancı cisim aspirasyonları (YCA); hava yollarının tıkanıklığı ile birlikte ortaya çıkan hayatı tehdit eden acil bir durumdur. Bu çalışma ile çocukların sürekli bakımlarını üstlenen annelerin çocukluk yaş grubunda ciddi sonuçlar doğurabilen YCA konusundaki bilgi düzeylerini ölçmeyi ve cevaplardan bağımsız olarak anneleri bilgilendirmeyi amaçladık. Gereç ve Yöntem: Çalışmaya 6 ay ile 5 yaş arasında çocuğu olan 1034 anne dahil edildi. Katılımcılara sosyodemografik özellikleri, YCA ile ilgili bilgileri soruldu. Bulgular: Çoğunlukla anneler; 21-30 yaşarasında (\%48.94), ilköğretim mezunu (\%34.62), ev hanımı (\%66.05) idi. Aileler genelde 2-3 çocuğa sahip idi. Annelerin çoğu (\%65.73) hayatlarında hiç YCA olan çocuk görmemişlerdi. Eğitim düzeylerine bağlı tüm gruplarda, en sık YCA görünen yaş grubu için 1-3 yaş seçeneği, en fazla üniversite mezunu katılımcılar (\%66.19) tarafindan işaretlenmişti. Eğitim düzeyiarttkça YCA'nın ölümcülolabileceği, koruyucu önlemlerin bütünlüğü, ilkmüdahalenin önemi ve müdahalede doğru bilginin kaynağı konularında farkındalığın arttğı gözlendi. Katılımcıların çoğu (\%72.74) YCA ile karşılaştkklarında acil servise başvuracaklarını belirtmişti. Sonuç: YCÁnın yol açacağı morbidite ve mortalitenin engellemesinde en önemli basamak önlenmesidir. Önlemenin de en kolay yolu toplumun bilinçlendirilmesi ve eğitilmesinden geçer.

Anahtar Kelimeler: Yabancı cisim; çocuk; anne; bilgi; tutum 


\section{INTRODUCTION}

Foreign body aspiration (FBA) is a life-threatening emergency that causes airway obstruction. (1) Although it can occur at any age, the risk is higher during childhood, as children are more vulnerable. (2) Young children in particular are more vulnerable to FBA due to lack of posterior molar teeth. Poor chewing of food and, consequently, an inability to swallow, accounts for this vulnerability. Besides the above, morbidity and mortality rates are higher in young children compared to other ages due to their narrow airways that have not yet fully grown and immature protective neuromuscular mechanisms. (3) While it is most common in children under six years of age, it occurs most frequently in children aged one to three years. (4) In terms of sex, it is slightly more prevalent in boys than in girls. (5)

This study aims to measure the amount of awareness there is about the life-threatening emergency FBA among Turkish mothers who are full-time carers of their children, and to provide these mothers with information regardless of their answers.

\section{MATERIAL AND METHODS}

1,034 mothers with children between the ages of six months and five years who admitted to any of the Pediatric Outpatient Clinics between 27/03/2018 and 27/08/2018 were included in the study.

Participants were asked to provide their sociodemographic information (age, level of education, employment status, age of child, number of children, number of people living in their household, monthly income in Turkish Lira) and to answer questions about FBA (whether they have ever seen a child experiencing FBA, how they identified FBA, in which age group and sex they think FBA is more prevalent, whether they feed their children while playing or standing, how dangerous FBA is, what they should do to prevent FBA, what they would do in the event of FBA, where they got this information from, when they should go to the hospital). The answers to the relevant questions were compared according to the mothers' level of education.

Mothers who agreed to participate in the study filled out the data collection form under supervision. Once the questionnaires were completed, the mothers' knowledge and awareness were improved by providing them with detailed pamphlets about FBA. Of the mothers who participated in the study, 13 were illiterate. A researcher read the questions and each of the options to them, explained these when needed, and received their answers verbally.

The approval of local Ethics Committee was received on 26/03/2018 (2018/50). All participants gave their written informed consent.

Statistical Analysis: All analyzes were performed using SPSS v21 (SPSS Inc., Chicago, IL, USA). Categorical variables were assessed using the Chi-square test and expressed with frequency (percentage) values, while $p$ values of $<0.05$ were considered statistically significant.

\section{RESULTS}

1,034 mothers whose children were aged between six months and five years participated in the study. The majority of the mothers were aged between 21-30 years old (48.94\%), primary school graduates (34.62\%), and housewives (66.05\%). The families had two to three children in general. Most of the mothers $(65.73 \%)$ had not seen a child experiencing FBA. Only a small portion (2.41\%) of the mothers that had seen a child experiencing FBA had been unable to identify it (Table 1).

If we compared the mothers according to level of education, "1-3 years" was mostly selected by the university graduates (66.19\%) as the age group in which FBA is most prevalent. As the level of education increased, the awareness regarding FBA's potential lethality, the importance of preventive measures, the importance of first response, and sources for correct information on how to intervene were seen to increase. While most of the participants (72.74\%) stated that they would take the child to the emergency room in the event of FBA, $10.96 \%$ selected "other". This option included hitting the child's back, performing maneuvers to remove the foreign body, calling 112 (emergency phone number in Turkey), applying first aid, and removing the object with their hand if it is clearly visible (Table 2). 
Table 1. Summary of individuals' characteristics

\begin{tabular}{|c|c|}
\hline Age & \\
\hline$<20$ & $114(11.03 \%)$ \\
\hline $21-30$ & $506(48.94 \%)$ \\
\hline $31-40$ & $330(31.91 \%)$ \\
\hline$>40$ & $84(8.12 \%)$ \\
\hline \multicolumn{2}{|l|}{ Level of Education } \\
\hline Illiterate & $13(1.26 \%)$ \\
\hline Literate & $112(10.83 \%)$ \\
\hline Primary School & $358(34.62 \%)$ \\
\hline High School & $269(26.02 \%)$ \\
\hline University or higher & $282(27.27 \%)$ \\
\hline \multicolumn{2}{|l|}{ Employment status } \\
\hline Housewife & $681(66.05 \%)$ \\
\hline Employed & $350(33.95 \%)$ \\
\hline \multicolumn{2}{|l|}{ Age of Child } \\
\hline 6 month -1 year & $237(22.94 \%)$ \\
\hline $1-3$ years & $398(38.53 \%)$ \\
\hline $3-5$ years & $398(38.53 \%)$ \\
\hline \multicolumn{2}{|l|}{ Number of Children } \\
\hline 1 & $328(31.75 \%)$ \\
\hline $2-3$ & $624(60.41 \%)$ \\
\hline $4-5$ & $62(6.00 \%)$ \\
\hline$>5$ & $19(1.84 \%)$ \\
\hline \multicolumn{2}{|c|}{ Number of People Living in the Household } \\
\hline $3-4$ & $657(63.66 \%)$ \\
\hline $5-6$ & $291(28.20 \%)$ \\
\hline$\geq 7$ & $84(8.14 \%)$ \\
\hline \multicolumn{2}{|c|}{ Income (Turkish Lira/month) } \\
\hline$<1000$ & $105(10.18 \%)$ \\
\hline $1000-2000$ & $310(30.07 \%)$ \\
\hline $2000-3000$ & $246(23.86 \%)$ \\
\hline$>3000$ & $370(35.89 \%)$ \\
\hline \multicolumn{2}{|c|}{ Have you ever seen a child experiencing FBA? } \\
\hline Yes & $375(36.27 \%)$ \\
\hline No & $659(63.73 \%)$ \\
\hline \multicolumn{2}{|c|}{ How did you identify FBA? } \\
\hline Difficulty in breathing & $191(51.21 \%)$ \\
\hline Cyanosis & $190(50.94 \%)$ \\
\hline Cough & $176(47.18 \%)$ \\
\hline Wheeze & $85(22.79 \%)$ \\
\hline Hoarse breath sounds & $82(21.98 \%)$ \\
\hline Vomiting & $15(4.02 \%)$ \\
\hline I could not & $9(2.41 \%)$ \\
\hline Data are given as frequ & \\
\hline
\end{tabular}


Table 2. Summary of individuals' answers according to level of education

\begin{tabular}{|c|c|c|c|c|c|}
\hline & \multicolumn{3}{|c|}{ Education } & \multirow[b]{2}{*}{ Total } & \multirow[b]{2}{*}{$\mathbf{p}$} \\
\hline & $\begin{array}{c}\text { Primary School or } \\
\text { lower } \\
(n=483)\end{array}$ & $\begin{array}{l}\text { High School } \\
\qquad(n=269)\end{array}$ & $\begin{array}{l}\text { University or } \\
\text { higher } \\
(n=282)\end{array}$ & & \\
\hline \multicolumn{6}{|c|}{ In which age group is FBA seen more prevalently? } \\
\hline $0-1$ & $121(25.10 \%)$ & $51(19.10 \%)$ & 56 (19.93\%) & $228(22.14 \%)$ & \multirow{5}{*}{$<0.001$} \\
\hline $1-3$ & $215(44.61 \%)$ & $154(57.68 \%)$ & $186(66.19 \%)$ & $555(53.88 \%)$ & \\
\hline $3-5$ & $48(9.96 \%)$ & $30(11.24 \%)$ & $24(8.54 \%)$ & $102(9.90 \%)$ & \\
\hline$>5$ & $17(3.53 \%)$ & $9(3.37 \%)$ & $6(2.14 \%)$ & $32(3.11 \%)$ & \\
\hline No idea & $81(16.80 \%)$ & $23(8.61 \%)$ & $9(3.20 \%)$ & $113(10.97 \%)$ & \\
\hline \multicolumn{6}{|c|}{ In which sex is FBA seen more prevalently? } \\
\hline Girls & 27 (5.59\%) & $13(4.85 \%)$ & $16(5.67 \%)$ & $56(5.42 \%)$ & \multirow{4}{*}{0.198} \\
\hline Boys & $90(18.63 \%)$ & $40(14.93 \%)$ & $61(21.63 \%)$ & $191(18.49 \%)$ & \\
\hline Both & $258(53.42 \%)$ & $167(62.31 \%)$ & $154(54.61 \%)$ & $579(56.05 \%)$ & \\
\hline No idea & $108(22.36 \%)$ & $48(17.91 \%)$ & $51(18.09 \%)$ & $207(20.04 \%)$ & \\
\hline \multicolumn{6}{|c|}{ Do you feed your child while playing/standing? } \\
\hline Yes & $179(37.14 \%)$ & $102(37.92 \%)$ & $71(25.18 \%)$ & $352(34.08 \%)$ & \multirow{2}{*}{0.001} \\
\hline No & $303(62.86 \%)$ & 167 (62.08\%) & $211(74.82 \%)$ & $681(65.92 \%)$ & \\
\hline \multicolumn{6}{|l|}{ How dangerous is FBA? } \\
\hline Not dangerous & $14(2.92 \%)$ & $3(1.12 \%)$ & $2(0.71 \%)$ & $19(1.84 \%)$ & \multirow{4}{*}{$<0.001$} \\
\hline Slightly dangerous & $91(18.96 \%)$ & $54(20.07 \%)$ & $36(12.81 \%)$ & $181(17.57 \%)$ & \\
\hline It could be lethal & $332(69.17 \%)$ & $203(75.46 \%)$ & $232(82.56 \%)$ & $767(74.47 \%)$ & \\
\hline No idea & $43(8.96 \%)$ & $9(3.35 \%)$ & $11(3.91 \%)$ & $63(6.12 \%)$ & \\
\hline \multicolumn{6}{|l|}{ What can be done to prevent FBA? } \\
\hline Should not give foods like nuts & $70(14.58 \%)$ & $29(10.78 \%)$ & $25(8.87 \%)$ & $124(12.03 \%)$ & \multirow{7}{*}{$<0.001$} \\
\hline Should check children frequently & $50(10.42 \%)$ & $33(12.27 \%)$ & $35(12.41 \%)$ & $118(11.45 \%)$ & \\
\hline Should feed them only while sitting & $83(17.29 \%)$ & $35(13.01 \%)$ & 35 (12.41\%) & $153(14.84 \%)$ & \\
\hline Should not give them small objects & $97(20.21 \%)$ & $44(16.36 \%)$ & $38(13.48 \%)$ & $179(17.36 \%)$ & \\
\hline All of the above & 265 (55.21\%) & $188(69.89 \%)$ & $213(75.53 \%)$ & $666(64.60 \%)$ & \\
\hline No need to do anything special & $18(3.75 \%)$ & $4(1.49 \%)$ & $2(0.71 \%)$ & $24(2.33 \%)$ & \\
\hline No idea & $18(3.75 \%)$ & $2(0.74 \%)$ & $0(0.00 \%)$ & $20(1.94 \%)$ & \\
\hline \multicolumn{6}{|l|}{ What will you do in case of FBA? } \\
\hline Take child to the primary care clinic & $66(13.72 \%)$ & $38(14.13 \%)$ & $14(4.98 \%)$ & $118(11.45 \%)$ & \multirow{5}{*}{$<0.001$} \\
\hline Take child to the emergency room & 340 (70.69\%) & $193(71.75 \%)$ & 217 (77.22\%) & $750(72.74 \%)$ & \\
\hline No need for treatment & $8(1.66 \%)$ & $1(0.37 \%)$ & $1(0.36 \%)$ & $10(0.97 \%)$ & \\
\hline No idea & $29(6.03 \%)$ & $10(3.72 \%)$ & $1(0.36 \%)$ & $40(3.88 \%)$ & \\
\hline Other & $38(7.90 \%)$ & $27(10.04 \%)$ & $48(17.08 \%)$ & $113(10.96 \%)$ & \\
\hline \multicolumn{6}{|l|}{ When should you go to the hospital? } \\
\hline Immediately & $407(84.44 \%)$ & $220(82.09 \%)$ & $258(91.49 \%)$ & $885(85.76 \%)$ & \multirow[t]{5}{*}{0.028} \\
\hline Next day & $7(1.45 \%)$ & $2(0.75 \%)$ & $3(1.06 \%)$ & $12(1.16 \%)$ & \\
\hline If the problems continue & $56(11.62 \%)$ & $42(15.67 \%)$ & $19(6.74 \%)$ & $117(11.34 \%)$ & \\
\hline No need to go & $4(0.83 \%)$ & $0(0.00 \%)$ & $1(0.35 \%)$ & $5(0.48 \%)$ & \\
\hline No idea & $8(1.66 \%)$ & $4(1.49 \%)$ & $1(0.35 \%)$ & $13(1.26 \%)$ & \\
\hline \multicolumn{6}{|c|}{ Where did you get this information from? } \\
\hline Healthcare personnel & $169(37.89 \%)$ & $123(48.43 \%)$ & $169(61.23 \%)$ & $461(47.23 \%)$ & \multirow{4}{*}{$<0.001$} \\
\hline Media / Internet / Social media & $140(31.39 \%)$ & $81(31.89 \%)$ & $67(24.28 \%)$ & $288(29.51 \%)$ & \\
\hline Family / Friends & $116(26.01 \%)$ & $54(21.26 \%)$ & $35(12.68 \%)$ & $205(21.00 \%)$ & \\
\hline No idea / did not receive information & $27(6.05 \%)$ & $7(2.76 \%)$ & $14(5.07 \%)$ & $48(4.92 \%)$ & \\
\hline
\end{tabular}




\section{DISCUSSION}

FBA is a common emergency that can have serious consequences if rapid intervention is not made. It is one of the most common domestic accidents suffered by children and one of the most common causes of accidental death. (6) The first death attributed to aspiration is thought to have occurred in $475 \mathrm{BC}$ when the Greek poet Anacreon died from aspirating a grape seed. (7) Most studies have shown that the probability of FBA occurring was high in the first five years. Its incidence was especially high in the first three years. $(8,9)$ The present study was conducted by evaluating the results of the questionnaire conducted with the mothers of children aged between six months and five years, which was indicated as the risky age group. The majority of the participants selected "1-3 years" as the age group in which FBA was more prevalent. Those who did not give an opinion were mostly mothers with a low level of education. The number of participants who selected the correct age group increased in direct proportion with the level of education. It seemed that the more educated a mother was the more waried they were of the risk of FBA, especially in young children.

The following can be considered as the reasons for the high prevalence of FBA in young children: poor chewing ability due to the lack of posterior teeth, insufficient swallowing coordination, tendency to explore the world with their mouths at that age, deep and frequent inhalation when stimulated for any reason, e.g. crying, laughing, surprised, and afraid, high level of physical activity, and insufficiently developed laryngeal elevation and glottic closure. Other risk factors include playing with toys that are not suitable for their age, being fed inappropriate foods, easy access to risky objects, parents setting a bad example for children, recklessness and negligence of caregivers, and ignorance of the family and lack of education. (2, 10) The participants were asked "Do you feed your child while playing or standing?" The majority (65.92\%) answered "No". However, conspicuously, one out of three mothers answered "Yes". Particular attention should be paid to feeding guides, which state that young children should not be fed when standing, playing, or moving. The answers received for this question were unsatisfactory. This shows that there is a need to educate mothers when it comes to feeding young children.

FBA is more common in boys than in girls. (11) The reason for this is thought to be that boys are more curious and active. (12) Most participants chose the option "Both" when asked in which sex FBA was seen more prevalently. The second most commonly selected option was "No idea". We are of the opinion that once caregivers have been properly educated on FBA, they will watch curious, energetic and active children more carefully, regardless of their sex.

Caregivers or healthcare professionals trained in first response perform the Heimlich maneuver at the time of FBA. This maneuver is roughly described as the responder placing their first between the costal margin and the navel, and applying pressure. During intervention in a young child, the child is laid down on the responder's lap, the first two fingers of both hands are placed between the costal margin and the navel, just next to the midline, and gentle upward pushes are applied. For a choking child younger than 12 months, a combination of back blows and chest thrusts is recommended. Abdominal thrust may cause damage and possible rupture of intra-abdominal organs and therefore it is not recommended in infants. (13) If a caregiver does not know first aid and identifies FBA, they should call the emergency line (112) immediately and ensure the child is treated by professionals. Deaths due to FBA are generally thought to occur in the pre-hospital period. (2) In one study, it was emphasized that of 27 FBA-related deaths, the families identified FBA in only half of the deaths. Ten of these deaths occurred before the child arrived at the hospital, seven occurred immediately after their arrival, and seven occurred within the first 24 hours. (14) In the present study, 74.47\% of the participants knew that FBA could be lethal. However, the remaining quarter of the mothers were unaware of how dangerous FBA was. This shows the importance of informing the public. Most of the participants stated that they would take the child to the emergency room $(72.74 \%)$ and immediately $(85.76 \%)$ in the event of FBA, while $10.96 \%$ selected the option "Other". This option included first aid steps instead. FBA is an emergency that requires urgent response. When performed correctly, the Heimlich maneuver can be a life-saving intervention. Effective immediate emergency intervention and raised public awareness on the subject will help protect society from the tragic consequences of FBA, which can be encountered at anytime, anywhere, regardless of age.

The type of foreign body aspirated may differ between communities, between regions within the same community, and even between cities in the same region. It is also affected by cultural and dietary habits. Accordingly, the most common foreign bodies were white beans and sunflower seeds in Turkey, pumpkin seeds in Greece, watermelon seeds in Egypt, and peanuts in the United States. (2) Other frequently aspirated foreign bodies include chewing gum, candy, pieces of food, toy parts, screws, pen/pencil lids, coins, and batteries. (15) Therefore, children's contact with these objects should be minimized and special attention should be paid during feeding. Breakable, small, hard foods (such as nuts) in particular should not be given to young children, and if they were to be given, they should be crushed and fed under the parents' supervision. Children should not be made to laugh while being fed, and sudden movements that could cause excitement or fear should 
be avoided. They should be fed while they were calm and sitting upright at their own table, rather than standing or moving. Children should not be given small toys, or toys that could be disassembled into small pieces, and the child should always be under the supervision of the caregiver when playing. It is also important that any toys purchased are suitable for their age and stage of development. (16) For the question "What can be done to prevent FBA?", a small number of mothers (4.27\%) selected the options "No need to do anything special" and "No idea". We think that through post-questionnaire education, we could ensure that these parents attach the necessary importance to preventing FBA.

FBA in children was commonly characterized by "a sudden onset of coughing and cyanosis and then wheezing while eating". Subsequently, the cough became persistent. (17) In addition, mild to severe respiratory distress, choking, fever, stridor, and wheezing could also be seen in patients. Sometimes, normal results might be obtained when a physical examination was performed on the patient. (18) But patients with FBA can also be presented to the hospital with pneumonia, pleural effusion, pneumothorax, atelectasis, and lung damage long after the non-persistent symptoms that occurred following aspiration. (19) We asked the participants how they identified FBA. While only $2.41 \%$ of the mothers stated that they could not identify it, half of them selected the options of difficulty in breathing, coughing, and cyanosis. This showed that there was not a serious lack of knowledge with regard to how to identify FBA in our region.

In a quasi-experimental study using internet-based educational video intervention, Bentivegna et al. found that after education, the participants generally improved their knowledge about the hazards of choking and how to prevent it. (20) In a study investigating FBA awareness among middle school and high school students, a significant lack of knowledge was observed. (21) One study conducted in Turkey emphasized that 50\% of mothers had insufficient knowledge about FBA, and that this deficiency could be solved through education. (22) We also thought that the mothers who participated in our study did not have sufficient levels of knowledge with regard to FBA. Only $47.23 \%$ of the participants had obtained information on the subject from healthcare professionals. The second most common sources of information were the media/ internet/social media. We think that the parents are unable to reach enough information about FBA. Therefore, plans must be made by using written and visual tools, by forming education groups, and by taking into account the majority of people's levels of education/knowledge.

\section{CONCLUSIONS}

As a result; the most important step in reducing the morbidity and mortality of FBA is prevention. The easiest route to prevention is education of parents and the raising of public awareness. In this study, we aimed to both evaluate the knowledge levels of 1,034 mothers, and to inform them about and raise their awareness of FBA with the educational pamphlets handed out after the questionnaire.

\section{ACKNOWLEDGEMENT}

Conflict of Interest: No conflict of interest was declared by the authors.

Financial Support: The authors declared that this case has received no financial support.

Ethical Approval: Ethics committee approval (Numbered: 2018/50 Date: 26.03.2018) was received from the ethics committee of Duzce University. All participants gave the written informed consent.

\section{REFERENCES}

1. Doğan M, Esen F, Doğan Y, Öztürk S, Demir ÖF, Öztürk MA. Çocukluk Çağındaki Trakeobronşiyal Yabancı Cisim Aspirasyonları. Bakırköy Tıp Dergisi 2019;15(2):126-130. DOI: 10.4274/BTDMJB.galenos.2018.20180216114524

2. Pekcan S, Aslan AT. Çocukluk çağında yabancı cisim aspirasyonları. Türkiye Çocuk Hastalıkları Derg 2010;4(2):119-128.

3. Sahin A, Meteroglu F, Eren S, Celik Y. Inhalation of foreign bodies in children: experience of 22 years. J Trauma Acute Care Surg 2013;74(2):658-663. DOI: 10.1097/TA.0b013e3182789520

4. Liu B, Ding F, An Y, Li Y, Pan Z, Wang G, et al. Occult foreign body aspirations in pediatric patients: 20-years of experience. BMC Pulm Med 2020;20(1):320. DOI: 10.1186/s12890-020-01356-8

5. Üstoğlu A, Zülfikar B, Tekant GT, Özcan R. Yabancı cisim aspirasyonu görülen 0-6 yaş çocukların ve ailelerinin özellikleri. Çoc Cer Derg 2018;32(3):93-102. DOI: 10.5222/JTAPS.2018.093 
6. Bentivegna KC, Borrup KT, Clough ME, Schoem SR. Basic choking education to improve parental knowledge. Int J Pediatr Otorhinolaryngol 2018;113:234-239. DOI: 10.1016/j.ijporl.2018.08.002

7. Tan HK, Brown K, McGill T, Kenna MA, Lund DP, Healy GB. Airway foreign bodies (FB): a 10-year review. Int J Pediatr Otorhinolaryngol 2000;56(2):91-99. DOI: 10.1016/s0165-5876(00)00391-8

8. Aslan N, Yıldızdaş D, Özden Ö, Yöntem A, Horoz ÖÖ, Kılıç S. Evaluation of foreign body aspiration cases in our pediatric intensive care unit: Single-center experience. Turk Pediatri Ars 2019;54(1):44-48. DOI: 10.14744/TurkPediatriArs.2019.60251

9. Cameron JL, Anderson RP, Zuidema GD. Aspiration pneumonia. A clinical and experimental review. J Surg Res 1967;7(1):4453. DOI: 10.1016/0022-4804(67)90009-1

10. Liman ŞT, Eliçora A, Topçu S. Yabancı cisim aspirasyonları ve özofagus yabancı cisimleri. Toraks Cerrahisi Bülteni 2012;3:94103. DOI:10.5152/tcb.2012.16

11. IIhan H. Çocuklarda yabancı cisim aspirasyonları. Çoc Cer Derg 2017;31(Supp: 1), 40-45. DOI:10.5222/JTAPS.2017.1010

12. Schmidt H, Manegold BC. Foreign body aspiration in children. Surgical endoscopy 2000;14(7):644-648. DOI: 10.1007/ s004640000142

13. Boufersaoui A, Smati L, Benhalla KN, Boukari R, Smail S, Anik K, et al. Foreign body aspiration in children: experience from 2624 patients. Int J Pediatr Otorhinolaryngol 2013;77(10):1683-1688. DOI: 10.1016/j.ijporl.2013.07.026

14. Paksu S, Paksu MS, Kilic M, Guner SN, Baysal K, Sancak R, et al. Foreign body aspiration in childhood: evaluation of diagnostic parameters. Pediatric emergency care 2012;28(3):259-264. DOI: 10.1097/PEC.0b013e3182494eb6

15. Rovin JD, Rodgers BM. Pediatric foreign body aspiration. Pediatrics in review 2000;21(3):86-90. DOI: 10.1542/pir.21-3-86 16. Shlizerman L, Mazzawi S, Rakover Y, Ashkenazi D. Foreign body aspiration in children: the effects of delayed diagnosis. Am J Otolaryngol 2010;31(5):320-324. DOI: 10.1016/j.amjoto.2009.03.007

17. Heyer CM, Bollmeier ME, Rossler L, Nuesslein TG, Stephan V, Bauer TT, et al. Evaluation of clinical, radiologic, and laboratory prebronchoscopy findings in children with suspected foreign body aspiration. J Pediatr Surg 2006 ;41(11):1882-1888. DOI: 10.1016/j.jpedsurg.2006.06.016

18. Mohammad M, Saleem M, Mahseeri M, Alabdallat I, Alomari A, Za'atreh A, et al. Foreign body aspiration in children: A study of children who lived or died following aspiration. Int J Pediatr Otorhinolaryngol 2017;98:29-31. DOI: 10.1016/j. ijporl.2017.04.029

19. Kök A. Yabancı Cisim Aspirasyonları. Güncel Göğüs Hastalıkları Serisi 2018;6(2):101-111. DOI: 10.5152/gghs.2018.022

20. Lee SL, Kim SS, Shekherdimian S, Ledbetter DJ. Complications as a result of the Heimlich maneuver. J Trauma 2009;66(3):E34-35. DOI: 10.1097/01.ta.0000219291.27245.90

21. Alshehri KA, Alharbi AA, Yaghmoor BE, Salman AK, Alaydarous SA, Abdalwassie LK, et al. Awareness of the first aid management of foreign body aspiration among students: A cross-sectional study. J Educ Health Promot 2019;8:220. DOI: 10.4103/ jehp.jehp_306_19

22. Ozdogan S, Sahin G, Avci O, Duran NB, Atli B. Akinci N, et al. Mothers' knowledge on foreign body aspiration. Yeditepe Med J 2015;11:935-944. DOI: 10.15659/yeditepemj.16.10.314 